[Boston, J. (1997). The Ownership, Governance, and Accountability of Tertiary Institutions in New Zealand. New Zealand Annual Review of Education, 6, 5-28]

\section{The Ownership, Governance, and Accountability of Tertiary Institutions in New Zealand}

\author{
JONATHAN BOSTON*
}

\begin{abstract}
:
Significant changes have been made since the late 1980s to the funding, governance, and accountability of New Zealand's public tertiary education institutions (TEIs). The new governance framework, which was introduced by the fourth Labour government in 1990, has been the subject of numerous criticisms. According to the government's departmental advisers on tertiary education, the new regime exposes the Crown to significant ownership risks, provides insufficient incentives for sound financial management, gives too much power to vested interests, unduly limits the government's capacity to intervene in the wider public interest, and leaves TEIs insufficiently accountable for their use of public resources. This article examines the merits of these criticisms, and assesses the various proposals for reform.
\end{abstract}

$\mathrm{O}$ ganisation is not merely a technical arrangement for work, authority, resources, and relationships. Alternative ways of organising an institution represent choices among competing values. This applies to all organisations, governmental or nongovernmental ... (Cameron, 1992, p. 167)

The question of how tertiary education should be funded - especially the proper balance between public and private contributions - has been the subject of intense public debate in New Zealand for many years. This debate has somewhat overshadowed a number of other critical policy issues in the tertiary arena, in particular those concerning the ownership, governance and accountability of tertiary institutions. According to various critics - including the Business Round table, the
6 Jonathan Boston

Treasury and some senior academics - the current governance framework is inherently flawed. For instance, it is argued that unlike most other public bodies, tertiary education institutions (TEIs) are not required to pay a capital charge; the financial reporting regime for TEIs is inadequate and they are not subject to proper external monitoring; the Crown bears a substantial ownership risk in TEIs, yet is relatively constrained in its capacity to control this risk; the performance of the councils of TEIs is hampered by their unwieldy size, the inclusion of internal stakeholders (i.e., staff and students), and a general lack of financial expertise; and the overall performance of TEIs is undermined by a range of input controls (e.g., in relation to borrowing, the issuing of debentures, the sale of assets, etc.).

In order to rectify these and other perceived weaknesses, various proposals for reform have been advanced. These include measures to strengthen the existing financial reporting and monitoring requirements, changes to the size and composition of councils, and the removal of the remaining input controls on TEIs. Much more radical reforms have also been suggested, such as the full privatization of TEIs (e.g., via management buy-outs), turning TEIs into non-profit trusts, and corporatising TEIs in a similar fashion to Crown Health Enterprises (CHEs), Crown Research Institutes (CRIs) and State-Owned Enterprises (SOEs). These latter suggestions would have profound implications for the character, structure and management of TEIs, and in some cases could pose a serious threat to significant values such as institutional autonomy and academic freedom. They thus raise fundamental policy issues regarding the proper design of tertiary institutions.

This article begins by outlining the current policy framework regarding the ownership, governance and accountability of TEIs following Labour's major legislative reforms in 1990. It then explores the nature of the criticisms levelled against the existing institutional arrangements, outlines some of the options for reform, and evaluates the merits of the case for further legislative and structural changes. Because of the breadth and complexity of the issues under examination, it is impossible in a relatively short article of this nature to do justice to all aspects of the subject. Accordingly, the issue of capital charging will be largely ignored. So too will matters relating to the funding of tuition and research, and the problems associated with the new qualifications framework. Other perspectives on some of the issues considered here can be found in Boston (1995); Butterworth and Tarling (1994); Ernst and Young (1995, 1996); Evans and Quigley (1996); Francis (1996a, 
1996b); Kerr (1995); Martin (1995); Peters (1996); Scott and Smelt (1995); and Wolff (1969).

\section{The Current Policy Framework}

New Zealand's tertiary sector comprises a relatively diverse range of institutions, including seven universities, 25 polytechnics, four colleges of education, two whare wananga and over 700 private training establishments (PTEs). In 1996 these institutions catered for more than 200,000 part-time and full-time students. Most of these students are eligible for state financial assistance (in the form of tuition subsidies, grants and income-contingent loans), with the government funding around $75 \%$ of total tuition costs (see Stephens and Boston, 1995). The Crown thus has a substantial and undisputed "purchase interest" in the tertiary sector.

The question of the Crown's "ownership interest" in TEIs, however, has been somewhat more contentious. In brief, TEIs are statutory corporations and for general purposes are separate from the Crown. Moreover, despite their status as "Crown entities" under the Fourth Schedule of the Public Finance Act 1989, it is generally agreed that they are not, at least in common law, owned by the Crown (see Crown Law Office, 1992a, 1992b; Tertiary Capital Charge Steering Group, 1994a, p. 2). Instead the assets of TEIs are deemed, under the Education Act 1989 , to be vested in each institution's governing body (i.e., the council). This makes TEIs different from CHEs, CRIs and SOEs, all of which are Crown-owned companies with shareholding ministers. Nonetheless, it is argued by many of the government's advisers that the Crown is the "in-substance" or "economic" owner of TEIs. Such a case rests on at least two grounds: first, the government's long-standing role as the primary funder and regulator of tertiary education; and second, its legal liability, under section 217 (6) (b) of the Education Act 1989, "to pay and discharge all the debts, liabilities, and obligations" of a TEI in the event that such an institution is disestablished (e.g., because of its financial difficulties). For such reasons, TEIs have been included in the Crown's balance sheet, with their net equity being estimated at $\$ 3.3$ billion in 1994. Whether the claim that the Crown is the in-substance owner of TEIs, especially universities, is justified is open to debate. Nevertheless, there can be little doubt that the Crown's legal responsibilities as the ultimate guarantor for the financial obligations of TEIs give it a legitimate ownership interest in the tertiary sector.
During the 1980s, New Zealand governments - along with their counterparts in many other jurisdictions (e.g., Australia, Britain, Canada, Sweden) - became increasingly concerned about the performance, governance, and external accountability of the country's tertiary institutions (see Cutt, 1990; Cutt and Dobell, 1990; Mahoney, 1994). Accordingly, as part of the fourth Labour government's wider reforms of the funding and management of the tertiary sector, important changes were made to the structures, powers and reporting requirements of TEIs (see Lange and Goff, 1989). These changes, which were embodied in the Education Act 1989 via the Education Amendment Act 1990, were designed to impose a unified approach to the governance and accountability of all public tertiary institutions, including polytechnics, teachers colleges and universities. In many respects, this involved giving polytechnics and teachers colleges a similar degree of autonomy to that traditionally enjoyed by universities, while at the same time introducing new regulatory, funding and accountability provisions across the whole tertiary sector.

Pivotal to the 1990 legislation was the aim of achieving a satisfactory balance between, on the one hand, the goals of institutional autonomy and academic freedom, and on the other hand, the desirability of ensuring that TEIs operate efficiently and effectively and are properly accountable for their use of public resources. This objective was given clear expression in section 160 of the Education Act:

The object of the provisions of this Act relating to [tertiary] institutions is to give them as much independence and freedom to make academic, operational, and management decisions as is consistent with the nature of the services they provide, the efficient use of national resources, the national interest, and the demands of accountability.

The Act goes on in section 161 to state that:

It is declared to be the intention of Parliament in enacting the provisions of this Act relating to institutions that academic freedom and the autonomy of institutions are to be preserved and enhanced.

Further, following a precise definition of the meaning of "academic freedom", the Act states firmly that:

In the performance of their functions the Council and chief executives of institutions, Ministers, and authorities and 
agencies of the Crown shall act in all respects so as to give effect

to the intention of Parliament as expressed in this section.

Under the Act, all TEIs are governed by a council. As specified in section 180, the functions of these councils are to appoint a chief executive, prepare and negotiate a Charter with the Secretary of Education, approve Statements of Objectives in accordance with section 41(2) (d) of the Public Finance Act, to ensure that the institution is managed in accordance with its Charter and Statement of Objectives, and to determine the policies of the institution in relation to the implementation of its Charter. In effect, then, councils have a "governance" rather than "management" role; their responsibility, in other words, lies in providing general oversight, direction and control. This includes monitoring their institution's financial and non-financial performance, holding the chief executive to account, approving significant policy and programme changes, giving proper attention to the institution's strategic direction, and building links with the wider community. Within this framework, council members are essentially trustees with a broad obligation of good stewardship. The responsibility for an institution's day-to-day management lies with the institution's chief executive (i.e., vice-chancellor or principal) and other senior administrators. Of course, as in other spheres of activity, the boundaries between governance and management are inevitably fluid, and it is impossible to draw absolutely precise and immutable lines of demarcation. Consequently, there are bound to be differences of view over the appropriate role of council members in certain situations.

As to the size and composition of councils, the 1990 legislation confirmed the existing predominantly "representative" model of governance which had hitherto applied in the university sector. Under section 171, councils must have between 12 and 20 members; they currently average around 17 . This means that they are larger than the boards of Crown-owned companies (which have between five and nine directors), but smaller than the governing bodies of equivalent institutions in various other countries, many of which have more than 30 members and some as many as 50 (Fieldea, 1996). Within these parameters, the Act provides for councils to include: four persons appointed by the Minister of Education; the institution's chief executive; between one and three members of the academic staff; between one and three members of the general staff; between one and three current or former students of the institution; a representative of the Employers' Federation; a representative of the Council of Trade Unions; and, where appropriate, representatives of relevant professional bodies. There is also flexibility within section 171 for other members to be coopted, appointed or elected in accordance with a council's constitution (e.g., representatives of local government and alumni).

Three features of the composition of councils deserve emphasis. First, by being able to appoint four members, the Minister of Education can ensure that all councils include people with certain kinds of expertise (e.g., financial) that might otherwise be lacking. At the same time, the Minister's appointees will always be in a minority, thereby reducing the risk that TEIs will be subject to unwarranted government interference. Second, the composition is deliberately inclusive and representative with all important internal and external stakeholders in the tertiary sector - including academic staff, general staff, current students, former students, and relevant community bodies - having a voice on councils. This representative model reflects the European (especially British) origins of New Zealand's educational institutions, including the emphasis on institutional autonomy, academic self-governance and collegial decision-making (particularly within universities). Third, the Act states (section 171 (4)) that TEI councils should seek to reflect the "ethnic and socio-economic diversity of the community served by" each institution. Councils must thus not merely represent various interests but should also be properly representative of the wider community (i.e., in terms of gender, ethnicity and social backgrounds).

Labour's reforms brought a number of changes to the relationship between the government and TEIs. The University Grants Committee was abolished, and all TEIs now relate directly to the Ministry of Education with regard to all funding and ownership issues. It is thus the Ministry which has the chief responsibility for monitoring both the financial and non-financial performance of TEIs and ensuring that the Crown's purchase and ownership interests are adequately protected. The main external accountability mechanisms, certainly on the purchase side, are Charters, Statements of Objectives, and Statements of Service Performance (see Deloitte Touche Tohmatsu, 1994). For instance, in keeping with parallel reforms in the compulsory education sector, tertiary institutions are required under section 184 of the Education Act to prepare written Charters specifying their goals and purposes. These Charters must be submitted to the Secretary of Education and approved by the Minister. The Act gives the Minister of Education the right to specify the kinds of matters which should be included in Charters, as 
well as the power to initiate amendments. Additionally, TEIs are required under the Public Finance Act 1989 (and other policy instruments) to prepare each year Statements of Objectives (setting out the classes of outputs to be produced during each of the following three academic years), a list of performance indicators, and Statements of Service Performance (SSP). The SSP, which are included in the Annual Report, compare the institution's outputs and performance with the targets contained in the Statement of Objectives. Also, by virtue of their status as Crown entities, TEIs must provide the Crown with annual financial statements, and are subject to review by the Audit Office. This includes scope for the Audit Office, under section 25 (3) of the Public Finance Act 1977, to investigate whether TEIs are using their resources "effectively and efficiently".

Finally, as part of Labour's reforms, a uniform funding regime was applied to all TEIs. Under the new approach, TEIs receive an annual bulk grant (reflecting their student numbers and adjusted by weightings for different course costs). Unlike the previous arrangements, the bulk grant covers capital expenditure in addition to normal operating costs. This gives TEIs greater management flexibility, particularly in relation to their capital development. At the same time, various input controls have been retained by the government. For instance, the State Services Commission is required to approve the conditions of employment of a tertiary institution's chief executive and must be consulted prior to TEIs commencing negotiations with staff over salaries and conditions. Further, TEIs are obliged under section 192 (4) of the Education Act to obtain the approval of the Secretary of Education before borrowing, issuing debentures, disposing of assets, or granting leases of land or buildings. Importantly, however, the Act also provides under section 192 (5) for the Minister of Education to approve parameters within which such activities can be carried out without requiring the consent of the Secretary, thereby giving TEIs much greater financial management flexibility. To date, only limited use has been made of this provision.

\section{Problems with the Existing Policy Framework}

Whatever improvements Labour's reforms brought about in the management of the tertiary sector, criticisms of the new governance and accountability arrangements were quick to emerge. Indeed, since the 1990 general election there has been sustained and concerted pressure on the government from its principal departmental advisers on tertiary matters (i.e., the Ministry of Education, the State Services Commission and the Treasury), as well as from various outside lobby groups, such as the Business Roundtable, for significant changes to the current policy regime. These pressures have prompted the establishment of various review groups and taskforces - e.g., the Tertiary Capital Charge Feasibility TaskForce (1991-1993), the Ministerial Consultative Group on tertiary funding (1993-94), the Tertiary Capital Charge Steering Group (1994- ), and the Tertiary Reference Group (1994- ) - as well as generating a steady stream of reports by departmental officials and external consultants (e.g., Deloitte Touche Tohmatsu, 1994; Ernst and Young, 1995, 1996). Meanwhile, various tertiary bodies have initiated their own examination of governance issues. In May 1995, the Council of Victoria University established an eight-person working party under the then Chancellor, Elizabeth Orr, to explore tertiary governance. Its first report - in the form of a discussion paper - was published in December 1995 (see Victoria University of Wellington, 1995); its final report is expected in early 1997. Also in 1995, the New Zealand Vice-Chancellors' Committee commissioned Graham Scott, a former Secretary to the Treasury, to prepare a report on the ownership and governance of New Zealand universities (see Scott and Smelt, 1995).

For various reasons, including the complexity of the matters under review, the political difficulties of passing controversial legislation during the transition to proportional representation, and opposition from within the tertiary sector, no significant policy changes in relation to tertiary governance have yet occurred. However, it is expected that with the political situation having been clarified following the first MMP election, the new National-New Zealand First coalition government may well initiate certain changes to the tertiary sector during the current parliamentary term. While the nature of these changes is uncertain (and in fact the Coalition Agreement is silent on the subject), the nature of the criticisms of the current governance framework has been widely canvassed. As summarized by the Treasury $(1996$, p. 115) in its post-election briefing to the incoming government in late 1996, the key concerns include the following:

- The nature and substance of the relationship between TEIs and the government remains unclear.

- Government is expected to have ultimate financial responsibility for TEIs, but has few means to secure its in-substance equity interests. 
- Councils of TEIs are not formally accountable to anyone, although individual council members represent the interests of different groups (students, staff, employers, local government or government).

- The ability of TEIs to run their day-to-day operations is still constrained by input controls, despite these no longer being the norm in the public sector.

- TEIs do not recognise the cost of capital and, as a result, do not properly assess the trade-offs between new and existing capital investments or face incentives to use resources efficiently.

According to the Treasury, the lack of clarity with respect to:

accountabilities and incentives has contributed to poor financial performance by some TEIs. The Ministry of Education has assessed the financial performance of three TEIs as being of serious concern, and has stepped up its monitoring of a further 20 TEIs (owing either to concerns about their financial performance, or to their borrowing and other financial activities) (Treasury, 1996, p. 115).

In mid-January 1997, shortly after the publication of this report, the Hon Wyatt Creech (Minister of Education) announced measures to improve the financial position of the Wanganui Regional Polytechnic. Having run deficits of up to $\$ 663,000$ each year since 1992, the Wanganui Polytechnic had sought a capital injection from the government. In response, the government commissioned an independent review by Ernst and Young, and, having considered its options, decided against providing additional funds. Instead, following discussions between the parties concerned, it was agreed that an independent observer would be appointed to the council (the first ever such appointment to a TEI governing body) to monitor its finances and provide advice, both to the Polytechnic and the government. Given that there is no statutory authority for the government to act in this manner, it was only able to do so with the concurrence of the Polytechnic. Additionally, two people with business and financial skills will be appointed by the Minister to the council, and the Polytechnic has agreed to strengthen its internal financial expertise and implement new financial and operational performance measures.
The recent developments at Wanganui Polytechnic (and previous problems at several other polytechnics) highlight the potential for TEIs to incur significant, on-going financial difficulties. Moreover, there is a real possibility that the frequency and magnitude of such difficulties may intensify in the future. Reasons for this include the increasing competition among public providers and between public and private providers, the declining level of public funding per student, the more competitive environment for research funding, the pressures on TEIs to engage in more entrepreneurial activities, declining student numbers in certain regions due to demographic trends and internal migration patterns, and the increasing levels of indebtedness of certain TEIs. In short, the Crown's ownership risk in the tertiary sector appears likely to increase over the coming years. There are thus good grounds for considering the adequacy of the current ownership monitoring framework and TEI governance structures.

Numerous proposals have been advanced by departmental officials, consultants and other advisers for changing the existing policy regime (e.g., see Ministry of Education, 1996; Scott and Smelt, 1995; Tertiary Capital Charge Steering Group, 1994a, 1994b; Treasury, 1996). Five of these will be considered here:

- extending the financial reporting requirements of TEIs;

- enhancing the options and powers available to the government to deal with institutions facing financial difficulties;

- altering the size and composition of councils;

- corporatizing TEIs along similar lines to CHEs, CRIs and SOEs; and - turning TEIs into charitable trusts.

The suggestion that TEIs should be turned into private, limited liability companies will not be discussed here. Not merely is such a proposal unlikely to be politically acceptable, but its intrinsic desirability is also highly doubtful. Similarly, no consideration is given to the proposition that the Crown's ownership and purchase interests in tertiary education should be separated at the ministerial level. Whatever the case for such a change, it is notable that in the Health portfolio the decision in 1993 to have two separate ministers (one to oversee the Crown's ownership interests and the other to oversee the Crown's purchase interests) has been abandoned by the new coalition government. 


\section{Evaluating the Options}

\section{The Ownership Monitoring Regime}

As it stands, the mandatory financial reporting requirements for TEIs are relatively weak, certainly when compared with many other Crown entities of comparable size and economic importance. For instance, Crown companies, such as CHEs, CRIs and SOEs, are subject to exacting reporting requirements, including the annual preparation of a Strategic Outlook, a comprehensive Business Plan, and Statements of Corporate Intent (in the case of CRIs and SOEs) and Statements of Intent (in the case of CHEs). Under existing arrangements CRIs and SOEs must report on their financial situation (against the relevant Business Plan and the SCI) on a quarterly basis. CHEs are currently subject to monthly reporting requirements. By comparison, TEIs are legally required only to provide annual financial statements. In order to strengthen the reporting regime, TEIs voluntarily agreed in 1994 to supply the Ministry of Education with a range of financial information on a six-monthly basis (and three-monthly where an institution is borrowing money or its financial viability is in question). This "interim ownership monitoring regime", as it is called, has undoubtedly improved the government's capacity to maintain financial oversight. However, it is voluntaristic in nature and does not include a multi-year strategic/financial planning phase (as required of CHEs, CRIs and SOEs).

Given this situation, a good case can be made for requiring TEIs, on a mandatory basis, to provide more regular and comprehensive financial information to a suitable Crown monitoring agency, be it the Ministry of Education, the Treasury or the Crown Company Monitoring Advisory Unit (or some combination of these bodies). Whether the reporting and monitoring requirements of TEIs ought to be exactly the same as those of CHEs, CRIs and SOEs is, of course, open to debate. After all, TEIs differ from Crown companies in terms of their ownership, capital structure, financial controls, sources of funding and overall ownership risk to the Crown. Moreover, none is facing annual deficits of the magnitude being incurred by most CHEs (which exceed $\$ 20$ million in a number of cases). A case can thus be made for a less exacting reporting regime.

\section{The Crown's Options for Intervention}

A further concern to the government and its advisers relates to the relatively limited options available to ministers for dealing with TEIs in financial difficulties. Leaving aside the use of informal pressure and voluntary arrangements of the kind adopted at Wanganui Polytechnic, the only statutory options are for the Minister of Education to strengthen the financial expertise of the council in question by appointing people with the relevant business skills, or to disestablish the institution under section 164 of the Education Act. Both courses of action have drawbacks. As already noted, the Minister is entitled to appoint only four members to a council, and there are legal and practical constraints on having such appointees removed. In the normal course of events, therefore, the strengthening of a council's financial expertise can only occur as the terms of the Crown's appointees expire. This is likely to be a slow process (unless, of course, the relevant council members respond cooperatively and voluntarily resign). The option of disestablishment is very much a last resort, only to be undertaken in extreme circumstances. As the Tertiary Capital Charge Steering Group (1994b, p. 7) puts it, such a step "would be cumbersome and controversial" and "would leave the Minister vulnerable to legal challenge". Accordingly, it is not a practical solution to most of the difficulties which TEIs are likely to suffer.

Various proposals have been advanced for providing the government with a wide range of options (short of disestablishment) to deal with TEIs in financial difficulties. These include: increasing the number of people the Minister of Education can appoint to councils; making it easier to replace the Crown's representatives on councils; enabling the imposition of stricter financial reporting requirements; enabling the government to appoint observers to councils; and replacing councils with an independent Commissioner. Each of these options has potential advantages and disadvantages. Changes to the composition of councils - which have been proposed for other reasons as well - will be considered shortly. Of the other options, statutory provisions for the appointment of an independent Commissioner are certainly worth considering. The main concern, of course, would be to ensure that the empowering legislation is drafted in such a way that measures of this kind could only be adopted in relatively grave circumstances when all other interventions of a less draconian nature have proved insufficient to deal with the institution's problems.

In considering the case for strengthening the Crown's powers for managing its ownership risk in TEIs, five general points are worth emphasising. First, in most circumstances a cooperative a pproach based on trust and proper consultation between the relevant parties is likely 
to be superior to a highly interventionist, centralized and mandatory approach.

Secondly, as the recent experience of CHEs and CRIs highlights, comprehensive ownership monitoring and more extensive powers of ministerial intervention do not prevent Crown entities from encountering major financial problems. Indeed, it is ironic, given such evidence, that some of the government's advisers are so committed to imposing upon TEIs the same governance and ownership monitoring framework which applies to Crown companies.

Thirdly, to some extent the Crown's increased ownership risk in relation to TEIs is the product of the government's cuts in tuition subsidies, its sometimes arbitrary changes to the funding of particular course categories, and its failure to reinstate a medium-term funding regime following the abandonment of the quinquennial block grants to universities in the late $1980 \mathrm{~s}$. A return to a more stable and predictable funding regime, with a clear political commitment to maintaining real levels of funding per student over the medium-term, would undoubtedly improve the capacity of TEIs to manage their finances and, in turn, reduce the risks of running significant deficits.

Fourthly, to the extent that the reporting requirements for TEIs are strengthened and additional powers are granted to ministers, there would be grounds for removing most, if not all, of the remaining input controls in relation to borrowing, the sale of assets, the setting of critical employment conditions, and so forth. Alternatively, the provisions of section 192 (5) of the Education Act could be invoked, thereby extending the financial flexibility of TEIs without altering the current statutory framework.

Finally, whatever the ownership risks which TEIs pose for the Crown, the main focus of the government's attention should be upon the quality and quantity of the educational and research services provided by TEIs. Put differently, the risks on the purchase side of the equation (i.e., the risks of poor educational outcomes) are arguably far greater than those on the ownership side - and are likely to remain so, certainly while the Crown remains the dominant funder of tuition costs and basic research. It would thus be unwise for the government and its advisers to devote their primary energies to the question of managing the Crown's ownership risk, as if this were the major issue facing the tertiary sector. At the same time, if the autonomy of TEIs is to be genuinely protected, any move by the Ministry of Education to institute highly specific and detailed purchase contracts must be firmly resisted.

\section{The Size and Composition of Councils}

The current size and composition of the councils of tertiary institutions has drawn sustained criticism since the early 1990s, most notably from the Ministry of Education, the State Services Commission, the Treasury and the Business Roundtable. Put briefly, it is argued that councils, as presently constituted, are too large to operate effectively, that they lack relevant expertise (especially in the area of business, finance and management), that they have inadequate incentives for prudent management, and that the inclusion of stakeholders is inconsistent with well-established principles of institutional design. More particularly, it is claimed that the inclusion of "internal agents" (i.e., the chief executive, and staff and student representatives) and interest groups (e.g., employer and union organisations) generates serious conflicts of interest (e.g., over the allocation of resources and the appointment of chief executives), exposes councils to the risk of "provider capture", encourages "rent seeking" (e.g., it makes councils more likely to devote resources to staff salaries than would otherwise be the case), and impairs institutional performance (see Tertiary Capital Charge Steering Group, 1994b).

Further, critics contend that good stewardship is incompatible with representative models of governance. That is to say, representatives are unlikely to be good stewards or trustees of the resources for which they have responsibility. To quote Victoria University's Working Party on Governance:

A strong argument can be made that the governing body should focus on its roles as stewards or trustees ... and not be made up in a representative fashion by stakeholders. The membership of the governing body should instead be expertise based: academic, financial, management, legal, fund raising, community relations, etc. (1995, pp. 20-21).

To bolster such assertions, it is claimed that overseas research (e.g., McCormick and Meiners, 1988; Toma, 1990) shows that

faculties function best when not represented on the governing body and that governing bodies may function best when not composed of representatives of key interest groups - so that they can seek to govern in the best interests of the institution rather than divide the spoils or otherwise seek political tradeoffs for the chief executive to implement (Scott and Smelt, 1995, p. 23). 
On the basis of such considerations, it is argued that the size of councils should be reduced to between eight and ten members, with a majority (or close to a majority) being a ppointed by the government (see Tertiary Capital Charge Steering Group, 1994, p. 9).

How robust are these criticisms of current council structures? Plainly, any evaluation of particular governance arrangements depends on the criteria used for assessment, the relative weight attached to these criteria, and the available evidence (see Public Policy Group, 1996). Often, each of these three elements - the criteria, the weighting and the evidence - will be the subject of vigorous debate, reflecting the differing values of the respective analysts and the problems of gathering and interpreting the relevant data. This particularly applies to the evaluation of complex, multi-purpose institutions producing outputs that are abstract in nature, and thus hard to specify and monitor. Tertiary institutions unquestionably fall into this category. Accordingly, there is a need to be circumspect when making claims about the relative merits of different governance frameworks.

The objection of many of the government's advisers to the use of representative models of governance reflects the managerialist and technocratic ethos which has dominated many of the recent reforms of New Zealand's public institutions (see Boston et al., 1996; Gregory, 1995). This ethos is antithetical to, or at least highly sceptical of, participatory and cooperative forms of decision-making (including concepts like industrial democracy, codetermination and stakeholder representation). It thus rejects governance structures in which agents have dual or multiple accountabilities or in which there is potential for provider capture. Instead, there is a strong preference for straight-line accountability between agents and a single principal, a clear separation of governance and management, and a reliance on technocratic and managerial expertise. Related to this, it is assumed that there is an "optimal" or single best organisational form for the conduct of most, if not all, human activities. More specifically, the private, for-profit, limited liability company (without stakeholder representation) is typically regarded as the most efficient and effective governance arrangement in most circumstances.

Such an approach to institutional design is open to numerous objections. First, the proposition that there is an optimal organisational form, including an optimal size for governing bodies, is highly dubious. Regarding TEIs (especially universities), it is evident from overseas experience over many centuries that high performance in the areas of teaching and research can be secured under a range of organisational forms (e.g., in terms of ownership, legal form, the size and composition of governing bodies, accountability mechanisms, etc.). Indeed, as the government's advisers readily admit, "some overseas universities of high reputation have very large governing bodies" (Tertiary Capital Charge Steering Group, 1994b, p. 6). Quite apart from this, the empirical evidence which is claimed to demonstrate the inefficiency of stakeholding participation in tertiary institutions is extremely limited, country specific (i.e., American), and open to challenge on various grounds (see Peters, 1996). The work of McCormick and Meiners (1988), for instance, deals primarily with the involvement of academic staff in internal university management rather than stakeholder representation on governing bodies.

Second, collective decision-making and representative models of governance are relatively common in certain fields of human endeavour, especially - but not solely - in the non-profit sector. It is notable, for instance, that most law firms and accountancy firms operate on the basis of partnerships, labour-managed firms are to be found in many jurisdictions, and worker representation on company boards is widespread in Germany. In relation to the tertiary sector, universities have long practised collegial forms of decision-making, even in situations where staff and students have not been represented on governing bodies. The proposition, therefore, that a specific commercial model of governance (i.e., the kind employed in Crown companies) should be applied to all Crown entities, irrespective of their functions, traditions, organisational culture and core values, is - to say the very least - questionable. Indeed, to the extent that institutional diversity provides for a richer cultural context and a more cooperative and resilient civil society, a good case can be made for maintaining both representative and non-representative models of governance (and mixed systems) within the public sector. Moreover, just as John Stuart Mill and others have contended that vigorous local government institutions are an important vehicle for building a strong democratic ethos, fostering a sense of citizenship, and providing a training ground for politicians at the national level, so too one could argue that participatory and representative institutions in other spheres of public life may also serve a similar purpose (see Pateman, 1975).

Third, institutional autonomy, a critical value in the tertiary arena (especially for universities), may be more difficult to preserve notwithstanding the provisions in sections 160 and 161 of the Education 
Act - if the government were to appoint a majority (or even close to a majority) of council members. Maintaining a majority of nongovernmental representatives is thus an important means of protecting long-standing academic values, especially academic freedom - and is arguably all the more necessary in a unitary state with a unicameral Parliament, a tradition of majoritarian governments, and the absence of an intermediary institution (such as the University Grants Committee) between the Ministry of Education and TEIs.

Turning to the more specific criticisms of stakeholder representation on tertiary councils, the following brief points can be made:

- Little empirical evidence has so far been presented to justify the claims regarding provider capture and rent seeking by internal stakeholders. In any case, internal stakeholders on tertiary councils do not enjoy a majority in most situations, on some issues (such as salaries and tuition fees) the views of staff and students often conflict, and, as a result of the legislative changes in 1990, chief executives replaced tertiary councils as the employer of staff. Quite apart from this, little attention is given by critics to the potential advantages of stakeholder representation in enhancing the commitment of staff and students to their particular TEI, providing councils with a wider range of opinions, information and expertise, making TEIs more responsive to the needs and interests of the communities they serve, and enhancing the transparency of decision-making (thereby improving public accountability).

- Conflicts of interest occur in all walks of life. The fact that they can arise for the representatives of internal stakeholders on tertiary councils is not a reason for abandoning the principle of representation. As in other situations when conflicts of interest arise, the simple solution is for the individuals in question to openly acknowledge their predicament and, where appropriate, absent themselves from participating in the relevant decision.

- Being a representative of a particular group or body is not inimical to being a good steward of the resources under one's care. Elected officials (MPs, councillors, members of school boards of trustees, etc.) fulfil these joint roles on a continuing basis. Were there to be a fundamental conflict between the roles of a representative and those of a steward or trustee, the whole rationale for democratic government would be called into question.
- Making "expertise", especially financial expertise, the primary criterion for selection to the governing body of a public institution implies a very technocratic approach to the management of public affairs. Well-educated lay people can and do make a valuable contribution to the governance of many organisations. Moreover, there has been increasing public pressure in recent years for including more lay people (or lay representatives) on the disciplinary and review panels of various professional bodies. The logic of the case advanced by officials would, if pressed to the limit, call into question the use of representative systems of governance in all spheres of life, from the running of schools to the conduct of the nation's affairs.

- On the question of size, there may well be a case for somewhat smaller councils than at present, and this is possible within the current legislative framework. However, a council of between eight and ten members, as proposed by officials, would provide only limited opportunity for stakeholder representation, particularly if the majority of the members were appointed by the government.

- Finally, which groups of stakeholders should be represented on TEI councils, and in what proportion, are questions upon which there is always likely to be disagreement. Internationally, many different approaches are in evidence, and no ideal model has so far emerged. In my view, there is a stronger case for having staff and students represented on councils than, say, employer and union representatives. As a general principle, however, it can be argued that TEIs should have reasonable flexibility in determining the precise balance of stakeholder representation. There is no inherent need, for instance, for the composition of the councils of universities and polytechnics to be identical.

\section{The CHE/CRI/SOE Model}

Some critics of the current framework of tertiary governance have argued that TEIs should be subject to the same, or similar, governance arrangements as apply to CHEs, CRIs and SOEs. Essentially, this would entail changing TEIs from statutory corporations into Crown-owned companies. Accordingly, TEIs would have boards of directors (of between five and nine members), all of whom would be appointed by the shareholding ministers. Boards would appoint their institution's chief executive, monitor his or her performance, set their institution's 
broad strategic objectives and ensure that the institution is managed in a prudent and responsible manner. Under this model, TEIs would be responsible for returning a profit on their activities and paying the Crown an appropriate dividend. They would also be obliged to comply with the reporting and monitoring regime discussed earlier. Advocates of such a model claim that it would increase management flexibility, enhance incentives for the efficient use of public resources, provide a more robust financial management regime, reduce the Crown's ownership risks, make TEIs more responsive to consumer interests, and enhance overall performance.

Against this, various objections can be raised. Of these, four deserve emphasis:

- As noted earlier, there could be significant risks to institutional autonomy under a framework in which all members of the governing body were ministerial appointees.

- It is yet to be demonstrated in areas like health and scientific research - which are comparable to tertiary education in terms of their heavy reliance on public funding and the importance of their non-commercial goals - that the Crown company model is superior to other organisational forms. Indeed, in the health arena the new coalition government is committed to making significant changes to CHEs, including removing their commercial objectives.

- It is significant that virtually all reputable tertiary institutions around the world are (and have always been) non-commercial in nature. This fact clearly relates to the nature of the activities they undertake and the core values to which academic institutions (particularly universities) have long been committed. Turning TEIs into for-profit organisations would almost certainly challenge their unique character and in all likelihood would significantly diminish TEIs' international standing (with negative implications for recruitment and retention). More specifically, it is extremely doubtful whether a commercial ethos would be compatible with the legal requirement for universities to act as a "critic and conscience of society".

- As already indicated, improving the ownership monitoring of TEIs and removing the current regime of input controls does not require fundamental changes to the governance and character of tertiary institutions.

\section{The Charitable Trust Model}

In their report to the Vice-Chancellors' Committee, Scott and Smelt (1995) argue that the best approach would be to turn universities (and, by extension, other TEIs) into charitable trusts (see also Kerr, 1995, pp. 10-12; Victoria University, 1995, pp. 23-24). Unlike the previous model, such trusts would be not-for-profit (though, of course, they could choose to undertake certain profit-making activities if this were compatible with the trust deed). Scott and Smelt maintain that, at least for TEIs, charitable trusts are a preferable organisational form to statutory corporations for the following reasons. First, such a change would remove, or at least significantly diminish, the Crown's exposure to financial risks in the tertiary sector. Second, there would be a number of advantages for TEIs:

- they would no longer be subject to Crown ownership monitoring;

- they would enjoy much greater management flexibility, including freedom to borrow;

- they would have an increased incentive for good performance due to the enhanced personal liability of trustees, the removal of the Crown's residual legal liabilities, and the fact that their governing bodies would be unlikely to include stakeholder representatives; and

- their independence, particularly from the state, would be easier to protect.

The fact that much depends on the nature of the trust deeds under which TEIs would operate complicates any assessment of the merits of the charitable trust model. Of particular importance would be the provisions regarding the role, size and composition of the governing body and the mechanisms established for consultation with staff and students. For instance, there is nothing in principle to stop a charitable trust having stakeholder representatives on its governing body. Trusts established on this basis would clearly be different in character from those where the government had the right to appoint all the trustees. Hence, without knowing the precise form of governance, the merits of the charitable trust model cannot be fully evaluated.

Having said this, it is by no means self-evident that the quality of trustees (somehow measured) would be higher under a trust model or that governing bodies would necessarily perform their duties more efficiently, effectively or prudently. Further, given that the state is likely 
to remain the principal funder of tertiary education and research, governments are unlikely to be indifferent if a TEI encounters serious financial difficulties, whatever its legal form or ownership structure. Accordingly, turning TEIs into trusts would not eliminate the Crown's ownership risk. Similarly, it is an open question as to whether academic freedom and institutional autonomy would be better protected under a trust model. Much would depend on the form and level of state funding, the financial strength of each trust, and the range of private sources of funding. In all likelihood, few of the trusts established under this model would have significant endowments. And even if they did, conflicts between the preferences of (potential) donors and the views of academic staff are not unknown at leading private universities elsewhere in the world (e.g., Yale in 1995). Finally, the external accountability of TEIs would arguably be weakened under a trust model. For instance, they would no longer automatically be bound by the requirements of the Official Information Act, the Ombudsmen Act, and the Public Finance Act.

\section{Conclusion}

It is perfectly proper for governments to expect that statutory corporations, such as TEIs, which have sizeable assets and receive substantial public funding are efficiently managed and adequately accountable for the public resources they employ. Equally, they have a right to expect that such institutions will operate prudently and thus not pose undue financial risks to the Crown. The problem of achieving these objectives in the case of TEIs is complicated by the need to protect a number of other vitally important values, namely institutional autonomy and academic freedom. Plainly, the more demanding the external accountability regime imposed on TEIs, the greater the risk that institutional autonomy will be compromised - for at some point external accountability becomes external control.

This article has considered the criticisms of the changes to the framework for tertiary governance embodied in the Education Act 1989, an Act which sought to find a politically acceptable and durable balance between the various competing values at stake. In my view, the current policy framework contains a number of weaknesses which require addressing. In particular, there is a good case for introducing a more robust system of ownership monitoring and for the Minister of Education to have a wider range of options for dealing with TEIs facing serious financial difficulties. Against this, the case for radical changes to the size and composition of TEI councils is weak, as are the arguments for abandoning the current statutory corporation model. For the future, the greatest risk to the autonomy of TEIs may well lie on the funding side - via the quest for highly specific purchase contracts - rather than from the imposition of a more extensive ownership monitoring regime.

\section{References}

Audit Office. (1996). Governance issues in Crown Entities. Report of the Controller and Auditor-General. Wellington: Audit Office.

Boston, J. (1995). The university as critic and conscience of society. In R. Pelly (Ed.), The university, ethics and society. Wellington: Combined Chaplaincies at Victoria University.

Boston, J., Martin, J., Pallot, J., \& Walsh, P. (1996). Public management: The New Zealand model. Auckland: Oxford University Press.

Butterworth, R., \& Tarling, N. (1994). A shakeup anyway: Government and the universities in a decade of reform. Auckland: Auckland University Press.

Cameron, D. (1992). Institutional management: How should the governance and management of universities in Canada accommodate changing circumstances? In J. Cutt and R. Dobell (Eds.), Public purse, public purpose: Autonomy and accountability in the groves of academe. Halifax: The Institute for Research on Public Policy.

Crown Law Office. (1992a). Correspondence from Bernard Banks to the Director of the Tertiary Implementation Section of the Ministry of Education, 27 February.

Crown Law Office. (1992b). Correspondence from Bernard Banks to Susan Glazebrook (Capital Charge Task Force), 22 July.

Cutt, J. (1990). Universities and government: A framework for accountability. Halifax: The Institute for Research on Public Policy.

Cutt, J., \& Dobell, R. (Eds.) (1992). Public purse, public purpose: Autonomy and accountability in the groves of academe. Halifax: The Institute for Research on Public Policy.

Deloitte Touche Tohmatsu. (1994). The Ministry of Education and the Treasury: A summary and comparison of crown company and tertiary education ownership monitoring in New Zealand. Wellington: Deloitte Touche Tohmatsu.

Ernst and Young. (1995). Ownership monitoring framework for tertiary educational institutions. Wellington: Ernst and Young. 
Ernst and Young. (1996). Overview of the proposed ownership monitoring process. Report for the Tertiary Capital Charge Steering Group. Wellington: Ernst and Young.

Evans, L. \& Quigley, N. (1996). University governance: Industrial organisation in the context of tertiary education. Victoria Economic Commentaries, 13, 1, 23-27.

Fieldea, J. (1996). The composition of university councils in the Commonwealth. $A B C D, 125,18-20$.

Francis, D. (1996a). Changes to the governance/ownership structures of New Zealand universities. Discussion Paper, Futures Management, Lincoln University.

Francis, D. (1996b). The ownership and monitoring relationship between the New Zealand Government and the universities. Draft MPP Thesis, Victoria University of Wellington.

Gregory, R. (1995). Bureaucratic "Psychopathology" and Technocratic Governance: Whither Responsibility? Hong Kong Public Administration, 4, 17-36.

Kerr, R. (1995). Promoting excellence in higher education. Paper presented to an AIC Conference on Tertiary Education, April 5.

Lange, D. \& Goff, P. (1989). Learning for life: Education and training beyond the age of fifteen. Wellington: New Zealand Government.

Ministry of Education. (1996). Briefing for the incoming Government. Wellington: Ministry of Education.

Martin, J. (1995). The university: Critic of society. In R. Pelly (Ed.), The university, ethics and society. Wellington: Combined Chaplaincies at Victoria University.

McCormick, R., \&Meiners, R. (1988). University governance: A property rights perspective. Journal of Law and Economics, 31, 423-442.

Mahoney, D. (1994). Government and the universities: The "New Mutuality" in Australian higher education - A national case study. Journal of Higher Education, 65, 2, 123-146.

Pateman, C. (1975). Participation and democratic theory. Cambridge: Cambridge University Press.

Peters, M. (1996). The not-for-profit trust model of ownershipand governance: The privatisation of New Zealand universities. A submission to the New Zealand Vice-Chancellors' Committee. University of Auckland.

Public Policy Group. (1996). The Working Party on University Governance discussion paper: A brief response. Victoria University of Wellington.
Scott, G., \& Smelt, S. (1995). Ownership of universities. A paper prepared for consideration by the New Zealand Vice-Chancellors' Committee. Wellington: Graham Scott (New Zealand) Ltd.

Stephens, B., \& Boston, J. (1995). Financing tertiary education: An evaluation of the Todd Taskforce. New Zealand Annual Review of Education, 4, 109-135.

Tertiary Capital Charge Steering Group. (1994a). Paper 4: A new ownership monitoring framework for tertiary education institutions. Paper to the Chair of the Cabinet Committee on Education, Training and Employment, Wellington.

Tertiary Capital Charge Steering Group. (1994b). Paper 5: The governance of tertiary education institutions. Paper to the Chair of the Cabinet Committee on Education, Training and Employment, Wellington.

Tertiary Capital Charge Steering Group. (1996). Development of enhanced ownership monitoring for tertiary education institutions. Wellington: The Treasury.

The Treasury. (1996). Briefing to the incoming Government. Wellington: The Treasury.

Toma, E. (1990). Boards of Trustees, agency problems, and university output. Public Choice, 67, 1-9.

Victoria University of Wellington. (1995). Working Party on Governance: Discussion paper. Wellington: Victoria University.

Wolff, R. (1969). The idea of the university. Boston: Beacon Press.

\section{The author}

Jonathan Boston is Associate Professor of Public Policy at Victoria University of Wellington. He has published books and articles on a range of public policy issues including incomes policy, the funding of tertiary education, aspects of social policy, and public management. He is currently a member of the "New Zealand Political Change Project", a three-year study of the impact of proportional representation on New Zealand's political system funded by the Foundation for Research, Science and Technology.

*The author wishes to thank Fiona Barker, Rob Crozier, Debbie Francis, Bob Gregory, Les Holborow, Delores Janiewski, Jane Kelsey and Lindsay Taiaroa for their helpful comments on an earlier draft of this paper. 